* Corresponding author

E-mail address:bpaw@prz.edu.pl

Article information

Article history: AMS-Volume16-No. 2-00179-12

Received 14 January 2012

Accepted 15 March 2012

\section{End-of-life Vehicle Recycling at the Disposal Stage}

\author{
B. Pawłowska \\ Technical University of Rzeszow, Al. Powstańców Warszawy 8, 35-959 Rzeszów, Poland
}

\section{KEY WORDS}

recycling, automotive vehicle, dismantling the end - of - life vehicle.

\begin{abstract}
Automobile recycling is a positive contribution to the reduction of many environmental impacts. In fact efficient utilization of resources by reusing discarded materials or using them as energy sources lessens the impact on the environment due to the depletion of natural resources and the potential pollution related to disposal to landfill. At present, approximately $75 \%$ to $80 \%$ of end-of-life vehicles in terms of weight is being recycled. However, the remaining $20 \%$ to $25 \%$ in weight, consisting of heterogeneous mix of materials (rubber, glass, textile, etc.) is still being discarded and disposed of as waste in landfills. In order to most effectively utilize the earth's resources and reduce the volume of disposable waste, automobile recycling activities must include efforts to further reduce the volume of this waste and promote its reuse at every stage of life cycle of vehicles. This paper presents car recycling opportunities at the disposal stage.
\end{abstract}

\section{Introduction}

In October 2000, the European Union adopted the End-of-Life Vehicles (ELV) directive (2000/53/EC) which seeks to prevent and limit waste and improve the re-use, recycling and recovery of ELVs and their components [1-4]. The directive also promotes eco-design, the usage of recycled materials and the improvement of the environmental performance of all of the economic operators (e.g. shredders, dismantlers) involved in the vehicle life-cycle.

The ELV directive's targets for re-use, recovery and disposal include:

- A minimum of $85 \%$ in weight of ELVs should be recovered as of 2006, including a maximum of $5 \%$ energy recovery, and, from 2015, a minimum of $95 \%$ in weight, including a maximum of $10 \%$ of energy recovery,

- Banning the use of hazardous substances, such as lead, mercury, cadmium and hexavalent chromium for new vehicles as from July 2003, excluding parts where it is essential for use [1-4].

A requirement of the directive is to make information about the above topics accessible to perspective buyers of vehicles.

Current recycling rates vary from country to country due to differences in the recycled/recovered materials markets, labour costs, landfill costs, and the levels of quality and professionalism in collection and dismantling, at treatment facilities and in technology.

Dismantling the end-of-life vehicle is the first step of the treatment process, and the accuracy and quality of this process determines the possibility of re-utilization and recycling of parts and components. 


\section{Dismantling the end - of - life vehicle}

During the dismantling process from end-of-life vehicles, dismantling companies first remove the oil, engine, transmission, tire, battery, catalytic converter, and other parts, which are commonly recycled (Fig.1) or reused [5-6].

Shredding companies then sort out the ferrous and non-ferrous metals and resin from the remaining vehicle bodies [7].

The remaining shredder residue, containing pieces of resin, rubber, glass and other items, was thought to be virtually impossible to recycle and disposed of as waste in landfills. In 1993, Toyota, together with Toyota Metal Co., Ltd., began to develop technology for effective utilization of shredder residue (Fig. 2, Fig.3) and then constructed the world's first mass-production recycling plant, with a capacity of recycling about 15,000 end-of-life vehicles per month [5].

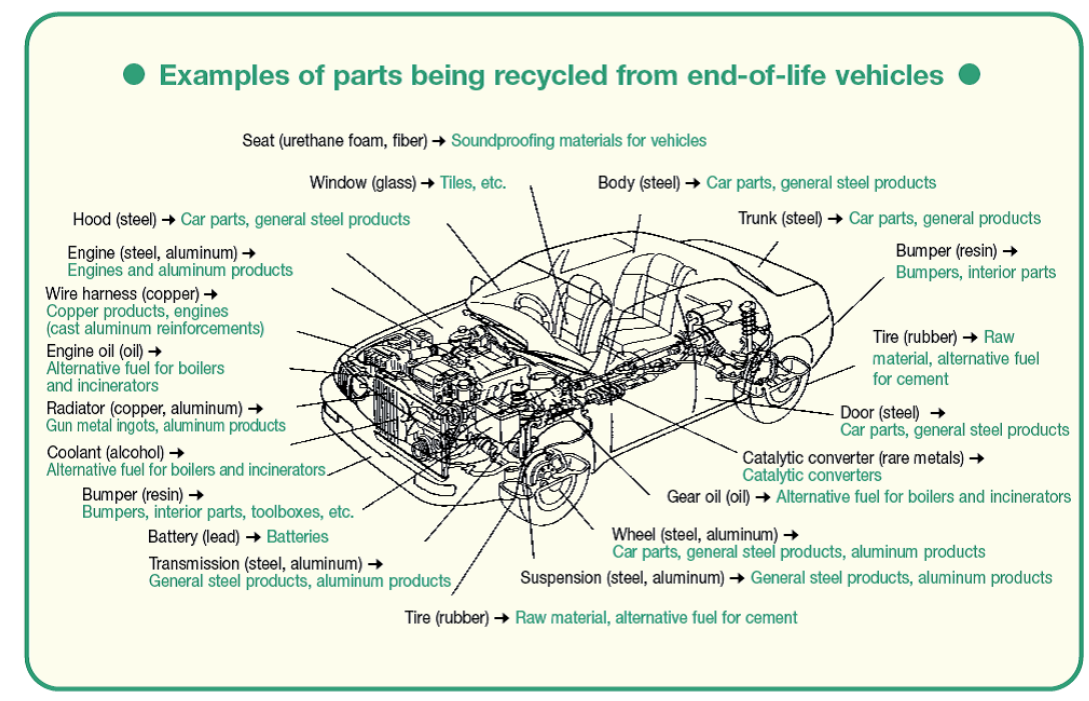

Fig. 1: Examples of parts being recycled from end-of-life vehicles [5]

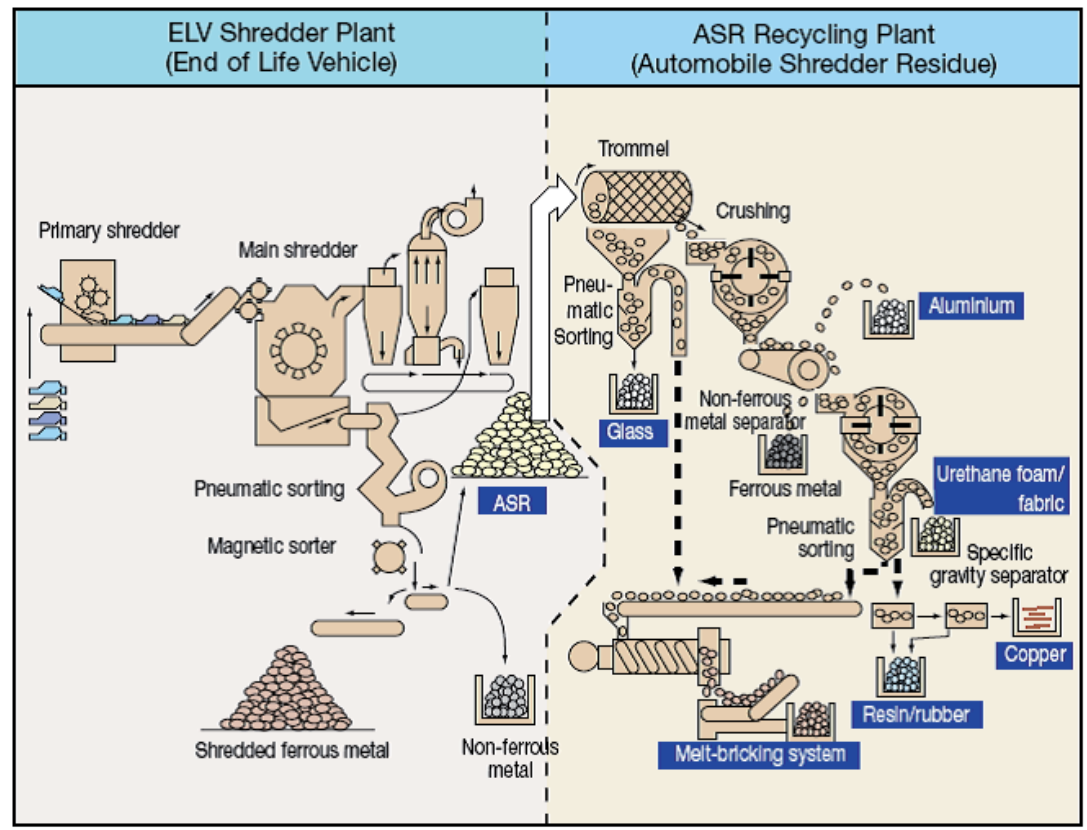

Fig. 2: Technology for effective utilization of shredder residue [5]. 


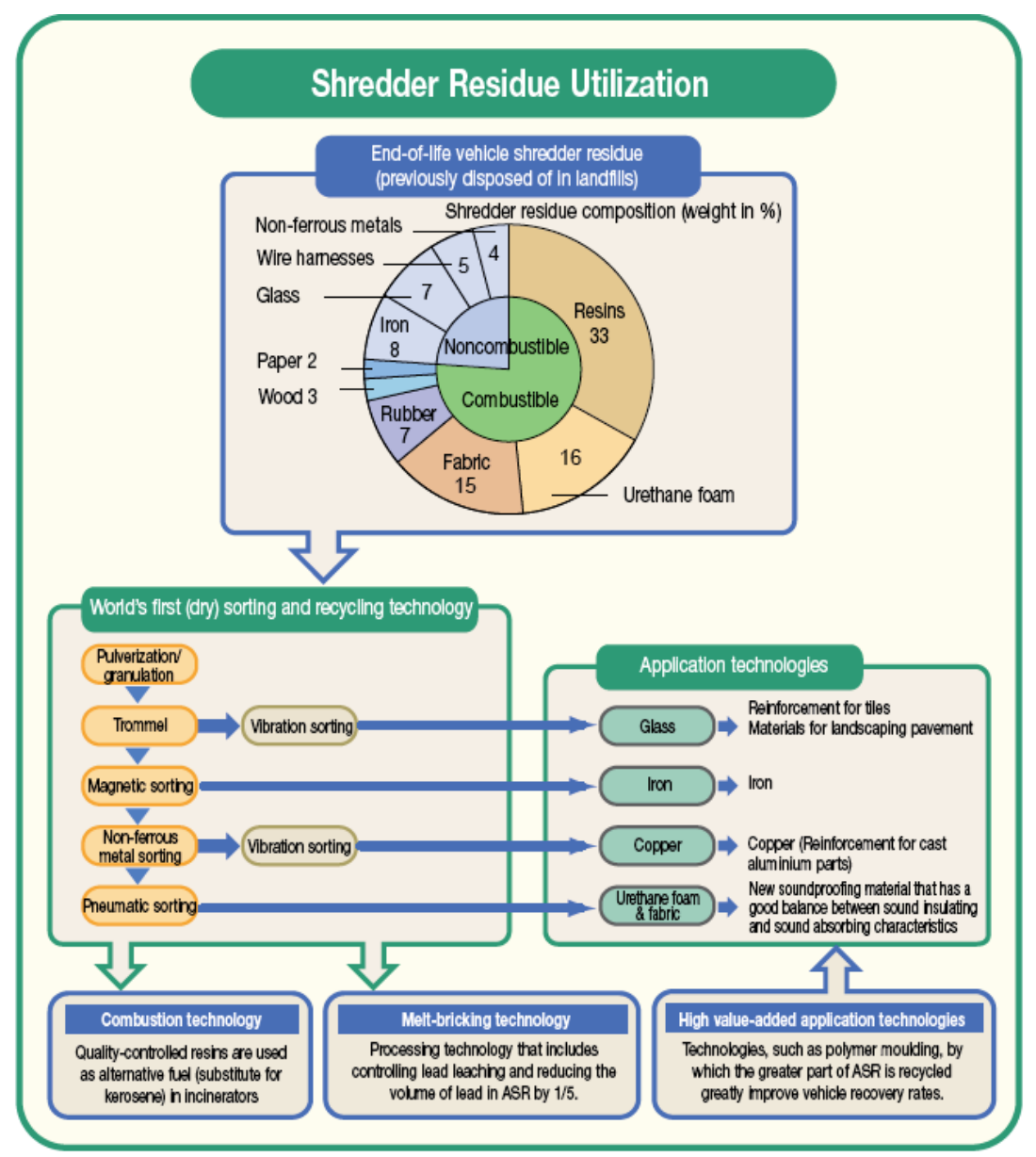

Fig. 3: Shredder residue utilization [5].

This centre provides research results for Toyota design divisions and provides information worldwide to help dismantling, shredding and recycling companies improve recycling methods.

\section{Effective utilization of shredder residue}

Toyota independently developed technologies for dry separation, sorting and recycling. By means of these technologies, the minute pieces of rubber, glass etc. in the shredder residue can be recycled into excellent, new material [5].

\section{- Development of RSPP}

Urethane foam and fabric, the major constituents of shredder residue, are sorted out and recycled into RSPP (Recycled Sound Proofing Products), a soundproofing material now being reused in several vehicle parts (Fig.4).

Compared to conventional products, this new soundproofing material has ample air pockets that

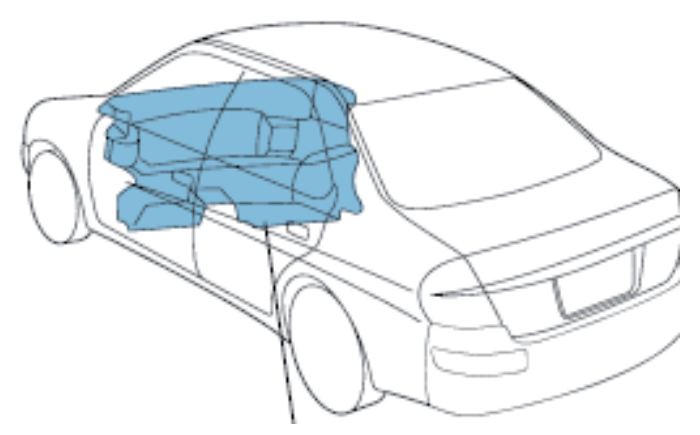

Fig. 4: Shredder residue utilization [5].

maintain a good balance between its sound insulating and sound absorbing characteristics for exceptional soundproofing performance [8].

\section{- Recycling of wire harnesses}

Toyota independently developed a high-precision sorter to separate wire harnesses. After the plastic shields and connectors are removed, the remaining copper (of purity $97 \%$ or above) is re- 
cycled. In Japan, the separated copper is currently being used at foundries as reinforcing material in aluminium castings [5].

\section{- Glass as raw material for the ceramic industry}

Utilizing the high-quality characteristics of automotive glass, powdered glass from shredder residue is recycled into tiles with remarkable density and strength, and also used as materials for landscaping pavement.

\section{- Alternative fuels}

The sorted resins form the bulk of shredder residue in terms of weight, and uniform pieces size. They have a high heating value on par with that of coal. This gives them the potential to be used as substitutes for coal and kerosene. Toyota, with Sanei Industry Co., Ltd., set out to research the possibility of using sorted resins as an alternative fuel, and succeeded in commercialization. This fuel has been in actual use in Japan since April 1999 [5].

\section{Rubber recycling technology}

Waste rubber generated in the production processes can also be recycled into regenerated rubber for automobile parts. Toyota developed the world's first waste rubber recycling technology in 1997 (Fig. 5) [5].

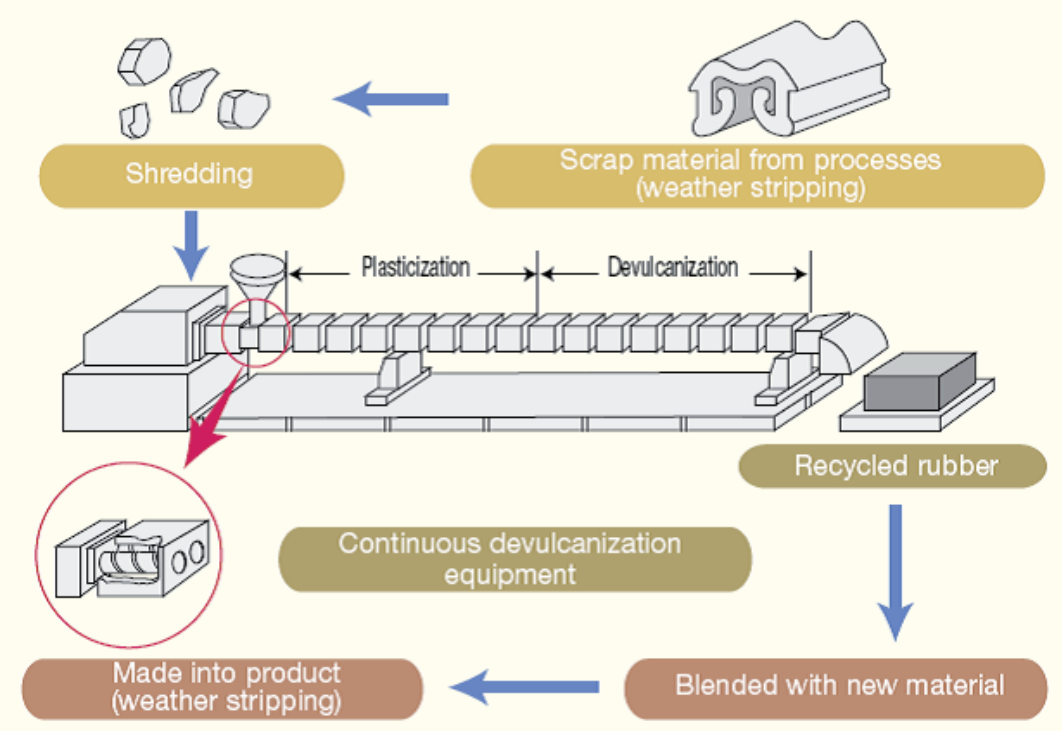

Fig. 5: New waste rubber recycling technology [5].

Full-scale application of this technology started in 1998. At present, approximately 200 tons per year of waste rubber is being recycled for Toyota vehicle production in Japan as weather stripping to waterproof vehicle doors and trunks.

\section{Conclusion}

Vehicle recycling activities have been going on successfully for more than 70 years. The existing infrastructure of dismantlers and shredders is capable of recovering $75 \%$ by weight of scrap cars. It is especially important to note that today vehicle recycling is profitable.

Recycling of automobiles can reduce costs for both manufacturers and consumers, and can vastly reduce the flow of material into the solid waste stream, thus helping to protect our environment. Working with consumers, dismantlers, shredders and suppliers, manufacturers act as a catalyst for promoting and advancing vehicle recycling in the marketplace.

When designing and building new vehicles, manufacturers strive to facilitate recycling at the end of the vehicle's life cycle through the selection and use of materials. At the same time, automakers must use recycled and recyclable material carefully to ensure that the safety and reliability of the finished vehicle are not compromised.

In order to continue and improve the impressive track record of the existing auto recycling industry it is essential to have a free market-based system of vehicle recovery. The driving force for increasing recycling rate should be profit opportunity.

The directive required that no later than 1 Janu- 
ary 2015, for all end-of life vehicles, the reuse and recovery shall be increased to a minimum of $95 \%$ by an average weight per vehicle and year.

Collaboration between collector, dismantler, and shredder are necessary to successfully meet the directive goals.

\section{References}

[1] Directive 2000/53/EC of the European Parliament and of the Council of 18 September 2000 on end-of life vehicles

[2] Zoboli R., Regulation and Innovation in the Area of End-ofLife Vehicles, EUR 19598 EN, 2000

[3] Materiał instruktażowy opracowany w ramach projektu współfinansowanego ze środków Unii Europejskiej Life04 env/pl/, branża motoryzacyjna

[4] Gwiazdowicz M., Problematyka recyklingu samochodów w Polsce oraz w projektowanych przepisach UE, Informacja nr 712, http,//biurose.sejm.gov.pl/teksty/i-712.htm

[5] www.toyota.pl

[6] Bocheński I., Recykling pojazdów samochodowych, Recykling, no 6, 2004

[7] Machnicka - Hławiczka M., Walczak K., Organizacja i projektowania stacji demontażu i recyklingu wyeksploatowanych samochodów, Recykling, no 7, 2003

[8] Bellmann K., Khare A., European Response to Issues in Recycling Car Plastics, Technovation, no 19, 1999, p. 721-734 